\title{
How International Political Conflict Hurts Country Image and further Influences Consumers' Purchase Intention
}

\author{
Mary Kang ${ }^{1}$, Sarah $\mathrm{Kim}^{1} \&$ Gukseong Lee ${ }^{2}$ \\ ${ }^{1}$ Business School, Hanyang University, South Korea \\ ${ }^{2}$ College of Business Administration, Kookmin University, South Korea \\ Correspondence: Gukseong Lee, College of Business Administration, Kookmin University, South Korea.
}

Received: November 2, 2017

Accepted: December 6, 2017

Online Published: January 8, 2018

doi:10.5539/ibr.v11n2p95

URL: https://doi.org/10.5539/ibr.v11n2p95

\begin{abstract}
Recently, South Korea's decision to deploy an advanced U.S. missile defense system has drawn neighboring China's strong protests. Amid this political tension between both countries, the purpose of this study is to explore the relationship between this specific political conflict and consumers' purchase intention. Based on previous literature, this study suggests a research model that defines the relationship between international political conflict, country image (i.e., affective country image and cognitive country image) and purchase intention. Proposed hypotheses suggest that international political conflict between foreign firms' host and home countries is negatively associated with consumers' purchase intention toward foreign firms' products in the host country by hurting cognitive and affective image of the home country. This study contributes to understanding the underlying mechanism on how international political conflict influences consumers' purchase intentions.
\end{abstract}

Keywords: international political conflict, affective country image, cognitive country image, consumers' purchase intention

\section{Introduction}

Since the establishment of South Korea-China diplomatic ties in 1992, South Korea and China have cooperated closely and made rapid development in various fields, such as tourism, trade, cultural exchange and so on. In 2015, annual trade volume between South Korea and China amounted to US\$ 227.3 billion, 40 times what the US\$ 5 billion it was at the start of diplomatic relations. On July 8, 2016, South Korea announced the decision to deploy the THAAD (Terminal High Altitude Area Defense), an advanced U.S. missile defense system. The Korean government has tried to emphasize that THAAD will serve as a safeguard to counter North Korea's missile threat, whereas the Chinese have perceived it as a threatening factor which is aimed to impair Chinese security interests, and therefore strongly opposed the system. To express strong objection, the Chinese state media and social network have criticized South Korea's decision over the issue, thus triggering rising discontent of Chinese towards Korea. Similarly, in 2012, China and Japan disputed over a chain of islands known as the Diaoyu in Chinese, putting the diplomatic relations between these two countries on ice. This was followed by China's boycott of Japanese products due to this territorial conflict between both countries (Wang, Li, Barnes, \& Ahn, 2012), which had a strong negative impact on bilateral trade, resulting in a one-year trade disruption of $2.7 \%$ (Heilmann, 2015).

In this way, international political conflicts are not only associated with political relationships, but also can influence economic and cultural activities between countries. Previous academic literature has also explored the results of international political conflicts in various areas such as trade, foreign direct investment, tourism, and cultural collaboration (Alvarez \& Campo, 2014; Heilmann, 2015; Huang, Wu, Yu, \& Zhang, 2015; Kastner, 2007). However, little is known about the impact of international political conflict on the individual consumers' purchasing behaviors. In today's interconnected world, more and more ordinary people are concerned by international events due to their wide dissemination through media and other channels. Therefore, it is expected that international political conflicts between countries not only hurt political relationships, but also influence an individual person's perception of a nation's image and their purchasing intention for the products produced by the nation in conflict. This, in turn, impact foreign firms' sales performance due to the conflicts between host country and home country. Consequently, it is important to investigate how such international political conflicts influence foreign firms' sales performance in the host country. Thus, this study aims to examine the relationship 
between international political conflicts and consumers' purchase intention in the host country. Further, this study would explore how the country image that includes affective country image and respect and reputation plays a mediating role in the mechanism mentioned above. We believe our research on the impact of political conflicts on consumers' purchase intention would provide insights for foreign firms' risk management when unexpected political conflicts arise between host country (or trading country) and home country, and also extend our understanding about why political conflicts influence trade at the macro-economic level.

\section{Literature Review and Hypotheses Development}

\subsection{Country Image}

Country image has always been regarded as a multi-dimensional concept (Han, 1989), including economical, technological, political and social variables of a country (Verlegh \& Steenkamp, 1999). In general, in wider perspectives, country image has been defined as "the total of all descriptive, inferential and informational beliefs one has about a particular country" (Martin \& Eroglu, 1993), or "a simplification of large number of associations and pieces of information connected with a place" (Kotler \& Gertner, 2002). Put simply, country image refers to the attitudes that people of one country hold toward another one (Maher \& Carter, 2011). Some scholars have paid more attention to country image's relation with product recognition (Agarwal \& Sikri, 1996; Roth \& Romeo, 1992), redefining country image as consumer's understanding of a specific country based on recognition of manufactured and marketed products from that country (Roth \& Romeo, 1992).

According to recent literature, country image comprises both cognitive and affective components. The cognitive dimension of country image refers to consumers' beliefs of a country, incorporating levels of economic development, living standards, industrialization, technological advancement and so forth (Wang et al., 2012), whereas affective country image includes emotions and feelings regarding a country as well as its people. Both components of country image are particularly distinct yet interrelated (Maher \& Carter, 2011). Additionally, people simultaneously hold inconsistent cognitive evaluations and affective ones toward a single country. For instance, Chinese have held a low affective country image of Japan for unclearly resolved historical problems and ongoing crises, but they subconsciously perceive Japan as a creative and advanced country, producing high-quality technical products. Wang et al. (2012) put forwards multiple comparisons of cognitive country image and affective country image of USA, Germany, Japan and Korea from Chinese perspectives, with the result showing that among the above countries, Korea was perceived to be relatively lower in cognitive country image, but tied Germany for highest affective country image. Some studies have also advocated conative evaluation of country image, which is defined as the behavior of the individual of the place (Alvarez \& Campo, 2014). However, the current consensus has agreed that country image can be evaluated by affective and cognitive dimensions, so in this paper, we will not take the conative component into consideration.

\subsection{International Political Conflict and Country Image}

International political conflict generally arises as a result of policy changes, government instability and other political forces across nations (Huang et al., 2015), essentially rooted in incompatible conflict of interest of respective nations. Numerous actual events concerning international political conflict have put forwards evidence that international political conflict negatively affects the image of the country involved. For instance, Alvarez and Campo (2014) addressed the conflict between Israel and Turkey. In May 2010, the Israeli military killed eight Turks and one Turkish-American aboard a Gaza-bound ship, the Mavi Marmara, which disregarded Israel's warning against entering their territory. The incident enraged Turks, whose nation suffered the most casualties, giving rise to strong Turkish animosity towards Israel. Alvarez and Campo (2014) compared the image of Israel from Turkish perspectives before and after the Mavi Marmara incident. They confirmed that Turks already held a very negative image of Israel even before the event, and the initial negative evaluation of Israel worsened after the conflict, especially in terms of feelings and emotions. In contrast, the Turks' opinion regarding Israel's level of technological, economic and industrial development became more positive, but this could not remedy the huge damage to Israel's overall country image. Analogously, in 2012, as the Diaoyu Islands conflict escalated, China-Japan relations deteriorated drastically, harming the images of both countries. In 2013, a Sino-Japan joint public opinion poll conducted by China Daily and Japanese Genron NPO suggested that more than nine tenths of the citizens of each country holds a bad image regarding the other country. As a result, diplomatic conflict between two countries could be a general public issue, affecting citizens' valuations and attitudes of the other country negatively. Animosity - defined as the remnants of antipathy related to previous or ongoing military, political, or economic events (Klein, Ettenson, \& Morris, 1998), plays a very important role in citizens' change of perceptions and preference towards a specific country. Instead of feeling "grievous and difficult to forgive"(Klein et al., 1998), they show animosity to reach a goal, for instance, to force a specific 
country to modify a policy and to protect their own interests. The influence of situational animosity on country image is temporary reducing with time, and some researchers found that, in the absence of new events and media attention to reinforce the negative image, the image returns to levels similar to those before the incident (Heslop, Lu, \& Cray, 2013). Even so, the temporary negative image could bring enormous economic loss and is likely exacerbate the conflict if not properly handled.

Before the emergence of THAAD, in recent years, the "Korean wave" from South Korea swept China by launching attractive and fashionable stars in various forms, amassing enormous numbers of Chinese fans. On the other hand, Korea's electronic and automotive technology has developed rapidly and companies, led by Samsung, LG, Hyundai along with their products, have been highly regarded in the Chinese market. Certainly, Korea has step by step gained a very positive country image in Chinese consumers' perceptions, both in affective and cognitive evaluations. Nevertheless, as the THAAD conflict broke out, things changed drastically. At first, the Chinese government attempted to persuade Korea to modify its decision to deploy THAAD. Subsequently, extensive media coverage reported on it and of course depicted it negatively, driving individual Chinese consumers' animosity towards Korea. Thus, we posit following hypotheses:

Hypothesis 1: International political conflict between foreign firms' host and home country is negatively associated with cognitive image of foreign firms' home country in the host country.

Hypothesis 2: International political conflict between foreign firms' host and home country is negatively associated with affective image of foreign firms' home country in the host country.

\subsection{Country Image and Consumers 'Purchase Intention}

A great amount of empirical observations and experiments have been made to discover how country image influences consumers' purchase intention. According to the previous studies, consumers often intensively feel that country of origin is changing their perspectives and evaluations towards product, subsequently playing a significant role in their decision to purchase. For instance, consumers are most willing to buy products from economically developed free countries (Wang \& Lamb, 1983). The country image effect is much more significant when the consumer is not familiar with a specific country's product, being defined as halo effect (Lin $\&$ Chen, 2006). This would not only affect the consumer's trust in the product, but also affect the consumer's overall evaluation of the product (Johansson, Douglas, \& Nonaka, 1985). However, both types of country image (i.e., cognitive and affective country image) influence consumers' purchasing intention with different ways.

Firstly, cognitive and affective country image influences purchase intention through quite different mechanisms. Findings suggested that affective country image tends to have a more direct effect on purchase intention compared to cognitive one (Maher \& Carter, 2011; Roth \& Diamantopoulos, 2009). Since the former is relatively independent with products, but related to consumers' personal feelings towards the firms' country, such as animosity, favor, which can directly make up consumers' minds in a sudden. Alternatively, cognitive country image influences purchase through product image (Wang et al., 2012). As product images are conceived as consisting of an array of information cues, both intrinsic (taste, design, fit) and extrinsic (price, brand name, warranties) (Bilkey \& Nes, 1982). And cognitive country image can provide with some of these information cues (Wang et al., 2012), thereby affecting product image invisibly.

Secondly, affective and cognitive country components do not always have an equivalent effect on purchase intention (Maher \& Carter, 2011). Affects and cognitions have impacts on different parts or types of the products. For instance, affective country image tends to determine action tendencies toward hedonic objects whereas cognitive country image influences action tendencies toward functional objects (Verlegh, 2001). Furthermore, they have different intensities of impact on purchase intention. Researchers have found that when a country's image has a strong affective component, its impact on product evaluations is stronger than its impact on product beliefs. Alternatively, when a country's image has a strong cognitive component, its direct influence on product evaluations was smaller than its influence on product beliefs (Laroche, Papadopoulos, Heslop, \& Mourali, 2005). To be specific, as mentioned above, during the territory conflict in 2012 related to Diaoyu Island, Chinese consumers' boycott of Japanese products appeared differently based on the product types. For functional products like electronic products and camera, even though there were extreme customers who destroyed their own Japanese cameras, many consumers still considered buying Japanese products based on the cognitive image of the country, therefore sales didn't waver a lot. On the other hand, for hedonic products, like fashion items, received a strong impact. Japanese fashion brand Uniqlo was boycott in China for a few months, and because the animosity toward the brand became too strong, they were forced to use a different shopping bag that has no logo on it. Moreover, while $30 \%$ of its store in China were close for a few weeks some stores also had to hide their brand logo. So now we are 
going to proceed further research on the decomposing effects of country image on purchase intention. As mentioned above, cognitive country image is less likely to be affected by political conflict compared with affective one, moreover, according to the research conducted on the topic of political issue between Turkey and Israel, it is found that Turks' opinion regarding Israel's level of technological, economic and industrial development part of cognitive country image even became more positive (Alvarez \& Campo, 2014). As a result, this paper will reduce the scope of cognitive country image and focus on the reputation and admiration part of cognitive country image, excluding the rest.

The study conducted by Yang asserted that country's reputation is a subject of increasing interest for the practice and research of public relations and public diplomacy and it could have certain influence on foreign publics' supportive intentions toward the country (Yang, Shin, Lee, \& Wrigley, 2008). Based on it, we can speculate that country's reputation can influence consumers' purchase intention. With respect to the influence of admiration towards a country, Maher, Clark, and Maher (2010) carried out investigation targeting Japanese product while Baillargeon (2004) conducted study about Argentine consumers' admiration towards the U.S and Canada. Both of them revealed that admiration towards a certain country is positively related to its products, in other words, admiration can positively affect both product evaluation and willingness to buy. In sum, there are sufficient existing literatures support the hypothesis on admiration and reputation's influence on purchase intention.

When it comes to the influence of affective country image towards purchase intention, at first, we will discuss the influence channeled through animosity. Up to now, many scholars have worked on the animosity model of foreign product purchase in diverse settings. For example, Klein et al. (1998)tested the model by using mainland Chinese consumers' attitudes towards Japanese products. Likewise, the boycott of French products by Australian and New Zealand consumers resulted from the nuclear tests by France in the South Pacific was also observed (Ettenson \& Gabrielle Klein, 2005). The study investigated the negative effect of consumer animosity on the purchase behavior of Egyptian consumers regarding Israeli products (Mostafa, 2010). These studies showed that animosity can be negatively associated with product evaluations, leading to weaker purchase intention and even boycotts. Although Japan, France, the U.S and some other developed countries are well-known for their high product image and quality, it is still possible that consumers feel resistance to their products. It is because the effects of animosity act on consumers' minds independently of products' judgement (Shin, 2001). Except animosity, there are lots of emotional factors that contribute to the effects of affective country image, such as anger, contempt, pity, alert, resistance and so on. These factors could not be enough to facilitate a boycott, but absolutely can make consumers to think twice before buy the products or take another product from other countries into consideration. Thus, we posit following hypotheses:

Hypothesis 3: Cognitive image of foreign firms' home country is negatively associated with consumers' purchase intention in the host country.

Hypothesis 4: Affective image of foreign firms' home country is negatively associated with consumers' purchase intention in the host country.

\subsection{Mediating Role of Country Image}

Based on above hypotheses, both affective country image and cognitive country image function as important mediating factors by transferring the effect of international political conflict to consumers' purchase intention. International political conflict is expected to hurt affective country image and cognitive country image, and these country images are further expected to have negative impacts on consumers' purchase intention. In sum, previous literature and practical cases could lead to a hypothesis that international political conflict negatively influence consumers purchase intention through hurting affective and cognitive country image. Thus, this study posits following hypotheses:

Hypothesis 5: International political conflict between foreign firms' host and home country is negatively associated with consumers' purchase intention in the host country by hurting affective image of home country.

Hypothesis 6: International political conflict between foreign firms' host and home country is negatively associated with consumers' purchase intention in the host country by hurting affective image of home country.

In addition, compared with affective image, cognitive image is more likely to be weakly dependent on political conflict. Therefore, previous studies argued that the influence of political incidents on the country image is greater with respect to its affective image than to its cognitive image (Alvarez \& Campo, 2014; Edwards, 1990). We also suggest that mediating effects of cognitive image and affective image on the relationship between international political conflict and consumers' purchase intention are different, and thus his study posit following hypothesis: 
Hypothesis 7: Affective image of foreign firms' home country transmits a stronger effect from international political conflict between foreign firms' host and home country to consumers' purchase intention in the host country than does cognitive image of home country.

Figure 1 presents a conceptual research model that explains the interrelationship among international political conflict, country image and purchase intention.

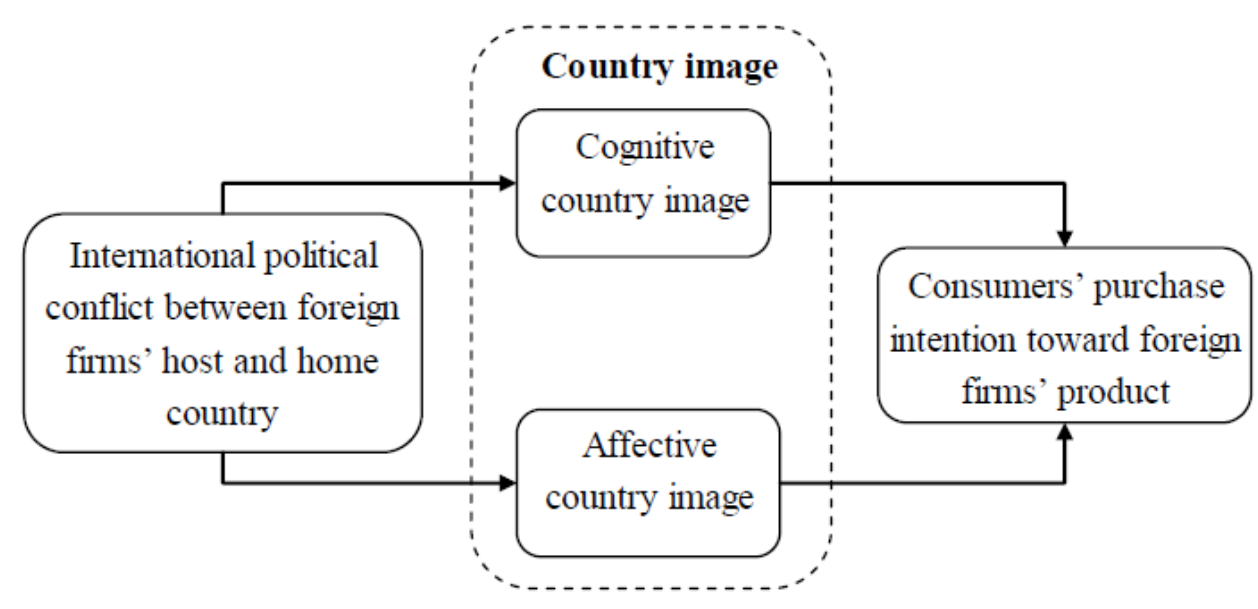

Figure 1. Conceptual research model

\section{Discussions}

This study proposes a research model that addresses how international political conflict hurts both affective and cognitive country image that further influences consumers' purchase intention. This study contributes to the literature on consumers' purchase intention by providing better understanding of how international political conflict hurts country image, and how different types of country image functions as a mechanism through which international political conflict affects consumers' purchase intention.

Previous studies on Chinese market from the perspective of Korean firms, researchers emphasized the positive impact of Korean cultural factors and marketing strategies using "Korean wave" on the market performance in China due to relatively good Korean country image in China (Hong \& Liu, 2009; Rho, 2013; Yoo, Jo, \& Jung, 2014). For instance, many Korean firms operating in China have used various commercials that hired Korean famous actors in order to penetrate Chinese market more efficiently. However, such measures are not likely to produce positive market performance when occurring international political conflict between both countries such as recent THAAD issue. Our research model reveals that international political conflict between foreign firms' home country and host country can hurt home country images in the host country and further influence consumers' purchase intention toward foreign firms' product. Therefore, if Korean firms try to use Korean country image in their marketing, it would more seriously frustrate Chinese consumers' purchase intention toward their products.

The firms from advanced country have been taking advantage of the emerging markets such as China and India by using their good image of their home country, since consumers are more likely to have good image toward these firms' products. However, such benefits are not always guaranteed. For the firms operating their business globally, international political conflicts are not predetermined and also become inevitable risk factors in doing their business. In the situation of international political conflict between countries, foreign firms need to more focus on product quality and better service providing in order to minimize the influence of bad country image and maintain consumers' purchase intention, instead of using country image that was positive impact on their business in good relationship between home and host countries.

In addition, mediating effects of cognitive image on the relationship between international political conflict and consumers' purchase intention is greater than those of affective image on this relationship. In other words, international political incidents between foreign firms' home and host countries has greater effect on the affective country image than does on the cognitive country image, and further influence consumers' purchase intention toward foreign firms' products in the host country. Therefore, firms operating their business in the host country that has political conflict relationship with their home country need to avoid some measures that utilize affective image of their home country. 


\section{Conclusions}

By proposing a research model that addresses the relationship between international political conflict, country image and consumers' purchase intention, this study provides useful insight in the ways that firms operating their business globally understand how international political conflict influences consumers' purchase intention toward their products. This study focuses on two types of country image (i.e., affective image and cognitive image) and emphasizes that different country image has different mediating effect between international political conflict and consumers' purchase intention. Country image as a transmitting mechanism between international political conflict and consumers' purchase intention can act as a double-edged sword, leading to positive consumer outcomes under good relationship between countries as well as negative consumer outcomes in the situation of international political conflict.

Since economic growth in emerging market outpaced developed markets, many international corporations are trying to enter emerging markets like China and India. The investment of the United States and Europe to China was increased by $52.6 \%$ and $41.3 \%$ each in 2016 . However, such companies operating in the foreign countries need to be careful about the political conflicts between those countries, because it is hard to predict the political conflicts that will occur in the future, and of course people's reaction toward the issue. Therefore, knowing how to cope with the problems caused by political conflict between their home country and host country is becoming a crucial competence in order to survive and thrive in the host country. Thus, this study will also explore the mechanisms that can help companies prepare for the potential loss due to future political conflicts. Therefore, it would be worth further investigating how foreign firms cope with risk factors caused by international political conflict between their home country and host country, thus providing more useful implications in the ways that such firms deal with bad country image of their home country. For instance, when a company tries to enter an emerging market, especially those countries with potential political conflicts, it might be better to choose localization strategy to penetrate the market.

In addition, considering these disparate outcomes of country image, further studying the relationship between country image and consumers' purchase intention by adopting moderating variables between this relationships, would be an interesting approach to expand our understanding of how to deal with county image for enhancing consumers purchase intention. Future research will explore the dynamic characteristics of the impact of international political conflict on the consumers purchasing intention and firm-level performance in the host country that has conflict with their home country.

\section{References}

Agarwal, S., \& Sikri, S. (1996). Country image: consumer evaluation of product category extensions. International Marketing Review, 13(4), 23-39. https://doi.org/10.1108/02651339610127239

Alvarez, M. D., \& Campo, S. (2014). The influence of political conflicts on country image and intention to visit: A study of Israel's image. Tourism Management, 40, 70-78.

https://doi.org/10.1016/j.tourman.2013.05.009

Baillargeon, J. C. (2004). Product-country images in the argentine setting: an analysis of animosity and admiration, MBA dissertation, Carleton University, Ottawa.

Bilkey, W. J., \& Nes, E. (1982). Country-of-Origin Effects on Product Evaluations. Journal of International Business Studies, 13(1), 89-100. https://doi.org/10.1057/palgrave.jibs.8490539

Edwards, K. (1990). The interplay of affect and cognition in attitude formation and change. Journal of Personality \& Social Psychology, 59(2), 202-216. https://doi.org/10.1037/0022-3514.59.2.202

Ettenson, R., \& Gabrielle Klein, J. (2005). The fallout from French nuclear testing in the South Pacific: A longitudinal study of consumer boycotts. International Marketing Review, 22(2), 199-224. https://doi.org/10.1108/02651330510593278

Han, C. M. (1989). Country Image: Halo or Summary Construct? Journal of Marketing Research, 26(2), 222-229. https://doi.org/10.2307/3172608

Heilmann, K. (2015). Does political conflict hurt trade? Evidence from consumer boycotts. Journal of International Economics, 99, 179-191. https://doi.org/10.1016/j.jinteco.2015.11.008

Heslop, L. A., Lu, I. R. R., \& Cray, D. (2013). Modeling country image effects through an international crisis. 
International Marketing Review, 25(4), 354-378. https://doi.org/10.1108/02651330810887440

Hong, K. H., \& Liu, J. (2009). Korean Fashion Brand Purchasing Behavior by Fashion Leadership and Korean Wave of College Women Students in China. Journal of the Korean Society of Clothing and Textiles, 33(4), 655-665. https://doi.org/10.5850/JKSCT.2009.33.4.655

Huang, T., Wu, F., Yu, J., \& Zhang, B. (2015). International political risk and government bond pricing. Journal of Banking \& Finance, 55, 393-405. https://doi.org/10.1016/j.jbankfin.2014.08.003

Johansson, J. K., Douglas, S. P., \& Nonaka, I. (1985). Assessing the impact of country of origin on product evaluations: a new methodological perspective. Journal of Marketing Research, 388-396. https://doi.org/10.2307/3151584

Kastner, S. L. (2007). When Do Conflicting Political Relations Affect International Trade? Journal of Conflict Resolution, 51(4), 664-688. https://doi.org/10.1177/0022002707302804

Klein, J. G., Ettenson, R., \& Morris, M. D. (1998). The Animosity Model of Foreign Product Purchase: An Empirical Test in the People's Republic of China. Journal of Marketing, 62(1), 89-100. https://doi.org/10.2307/1251805

Kotler, P., \& Gertner, D. (2002). Country as brand, product, and beyond: A place marketing and brand management perspective. Journal of Brand Management, 9(4), 249-261. https://doi.org/10.1057/palgrave.bm.2540076

Laroche, M., Papadopoulos, N., Heslop, L. A., \& Mourali, M. (2005). The influence of country image structure on consumer evaluations of foreign products. International Marketing Review, 22(1), 96-115. https://doi.org/10.1108/02651330510581190

Lin, L.-Y., \& Chen, C.-S. (2006). The influence of the country-of-origin image, product knowledge and product involvement on consumer purchase decisions: an empirical study of insurance and catering services in Taiwan. Journal of Consumer Marketing, 23(5), 248-265.

https://doi.org/10.1108/07363760610681655

Maher, A. A., \& Carter, L. L. (2011). The affective and cognitive components of country image: Perceptions of American products in Kuwait. International Marketing Review, 28(6), 559-580. https://doi.org/10.1108/02651331111181411

Maher, A. A., Clark, P., \& Maher, A. (2010). International consumer admiration and the persistence of animosity. Journal of Consumer Marketing, 27(5), 414-424. https://doi.org/10.1108/07363761011063312

Martin, I. M., \& Eroglu, S. (1993). Measuring a multi-dimensional construct: Country image. Journal of Business Research, 28(3), 191-210. https://doi.org/10.1016/0148-2963(93)90047-S

Mostafa, M. M. (2010). A structural equation analysis of the animosity model of foreign product purchase in Egypt. Global business review, 11(3), 347-363. https://doi.org/10.1177/097215091001100303

Rho, H. (2013). An Empirical Study on the Effect of Korean Wave on the Brand Loyalty of Korean Products in Chinese Market. Journal of the Korean Society of Clothing \& Textiles, 18(5). https://doi.org/10.9708/jksci.2013.18.5.157

Roth, K. P., \& Diamantopoulos, A. (2009). Advancing the country image construct. Journal of Business Research, 62(7), 726-740. https://doi.org/10.1016/j.jbusres.2008.05.014

Roth, M. S., \& Romeo, J. B. (1992). Matching Product Catgeory and Country Image Perceptions: A Framework for Managing Country-of-Origin Effects. Journal of International Business Studies, 23(3), 477-497. https://doi.org/10.1057/palgrave.jibs.8490276

Shin, M. (2001). The animosity model of foreign product purchase revisited: does it work in Korea? Journal of Empirical Generalisations in Marketing Science, 6(1). 
https://www.empgens.com/wp-content/uploads/2001/06/AnimosityModel.pdf

Verlegh, P. W. (2001). Country-of-origin effects on consumer product evaluations: Wageningen Univ.

Verlegh, P. W. J., \& Steenkamp, J. B. E. M. (1999). A review and meta-analysis of country-of-origin research. Journal of Economic Psychology, 20(5), 521-546. https://doi.org/10.1016/S0167-4870(99)00023-9

Wang, C.-K., \& Lamb, C. W. (1983). The impact of selected environmental forces upon consumers' willingness to buy foreign products. Journal of the Academy of marketing Science, 11(1-2), 71-84. https://doi.org/10.1007/BF02721862

Wang, C. L., Li, D., Barnes, B. R., \& Ahn, J. (2012). Country image, product image and consumer purchase intention: Evidence from an emerging economy. International Business Review, 21(6), 1041-1051. https://doi.org/10.1016/j.ibusrev.2011.11.010

Yang, S.-U., Shin, H., Lee, J.-H., \& Wrigley, B. (2008). Country reputation in multidimensions: Predictors, effects, and communication channels. Journal of Public Relations Research, 20(4), 421-440. https://doi.org/10.1080/10627260802153579

Yoo, J. W., Jo, S., \& Jung, J. (2014). The effects of television viewing, cultural proximity, and ethnocentrism on country image. Social Behavior \& Personality An International Journal, 42(1), 89-96. https://doi.org/10.2224/sbp.2014.42.1.89

\section{Copyrights}

Copyright for this article is retained by the author(s), with first publication rights granted to the journal.

This is an open-access article distributed under the terms and conditions of the Creative Commons Attribution license (http://creativecommons.org/licenses/by/4.0/). 